Брежнева Анаст асия Игоревна магистрант

ФГАОУ ВО «Северо-Кавказский федеральный университет»

г. Ставрополь, Ставропольский край Климовских Юлия Александровна канд. филол. наук, доцент Институт экономики и управления ФГАОУ ВО «Северо-Кавказский федеральный университет»

г. Ставрополь, Ставропольский край Ткаченко Анастасия Евгеньевна канд. полит. наук, доцент Институт экономики и управления ФГАОУ ВО «Северо-Кавказский федеральный университет» г. Ставрополь, Ставропольский край

DOI $10.21661 / r-475075$

\title{
PECULIARITIES OF SOCIAL NETWORKS PROMOTION OF A FIRM
}

Аннотация: данная статья посвящена такому актуальному вопросу, как SМM. Раскрывается отсутствие единой меры эффективности SMM. Aвторы рассказывают о необходимости проведения исследований и создании единьх критериев измерения эффективности работы специиалистов SMM.

Ключевые слова: реклама, маркетинг в сочиальных сетях, поисковая оптимизация, соцчиальные сети.

Abstract: this article focuses on such relevant issue as SMM. It also reveals such an aspect as the absence of a unified measure of the effectiveness of SMM. The authors tell about the need for research and the creation of uniform criteria for measuring the effectiveness of the work of SMM specialists. 
Keywords: advertisement, social media marketing, Search Engine Optimization, social networks.

In the modern world it is difficult to imagine an effective business, without promotion in social networks. Earlier SMM (Social Media Marketing (SMM)) was used mainly by young people. But now, there are departments in every large company that do this professionally or give this niche for outsourcing. We can't ignore the importance of promotion by means of various social platforms, as it becomes simply impossible. One of the main purposes of employing social media in marketing is finding out a communication tool that makes the companies accessible to people who show interest for their product and makes them visible to those who have no knowledge of their products. These companies use social media to create buzz, and learn their target customers.

But there is still no single metric been developed to measure the performance indicators of a particular advertisement. Most SMM-specialists use such indicators of the result of their work as increase in the number of subscribers, audience coverage and number of views. But all these indicators are extremely subjective. The purpose of our research is to study the indicators for measuring the effectiveness of various types of SMM advertising.

For us, this topic is particularly relevant. The knowledge that we get, we can immediately test in practice. Especially the topic is interesting because it is rapidly developed.

This summer we took part in SMM forum, which took part in Stavropol. It was organized by SMM agency «Vilk me». During several days of training, we studied all the trends of SMM advertising and touched targeted advertising on Facebook. This topic is not so easy, as it can seem to be. We studied such issues as:

- how to sell your goods or service with the help of «direct»;

- what client needs (useful sales scripts);

- how to set up targeted advertising;

- creating of visual content. 
Though the forum was very useful, there was little information about indicators that can show us the effectiveness of those instruments in work. At that moment we realized that the topic of performance indicators was not still studied deeply. Here are the main sources of information for research:

- web analytics data (traffic, activity users, performing targeted actions);

- analysis of user actions in social networks

(«Like» marks, comments added materials);

- internal statistics of communities and blogs in social networks (attendance, number of views pages, audience profile, etc.);

- monitoring data from social networks and blogs (number of mentions, their tonality, resonance);

- open stats statistics on third-party sites (number of views on video aggregators, number of visits to topics on the forums etc.);

- classical sociological tools, adapted to social networks (polls, work with focus groups, etc.);

- special marketing activities (system promotional codes, allocated phone numbers etc.).

These data serve as the basis for further analysis.

We should also consider such a metric as sales. It is necessary to make an important clarification. This indicator can be effectively calculated. Only for companies oriented direct sales: online stores, retail stores, etc. If there is a complicated cycle (as, for example, in the FMCG sector or in the film industry), it is almost impossible to track down the source of each sale. Therefore, in such campaigns other metrics that indirectly reflect impact on sales. There are several tracking mechanisms sources of sales: web analytics and dedicated phone number.

The relevance of this topic is due to the fact that it is quite modern, there is little theory, trends change every day, so you need to be watchful all the time.

The main goal of our research is to study effective tools for working in social networks, the use of targeted advertising, contextual advertising and SEO (Search Engine Optimization) promotion. Search engine optimization (SEO) is the process of 
affecting the online visibility of a website or a web page in a web search engine's unpaid results - often referred to as «natural», «organic», or «earned» results. In general, the earlier (or higher ranked page), and more frequently a website appears in the search results list, the more visitors will receive it from the search engine's users; these visitors can then be converted into customers. SEO may target different kinds of search, including image search, video search, academic search, news search, and industry-specific vertical search engines.

To implement the objectives of the study, the following tasks were set:

- to give a definition of targeted online advertising;

- to conduct a business analysis of various indicators targeted and SEO companies;

- to propose new algorithms for measuring targeted advertising and SEO promotion for making effective management decisions.

The master's research in the methodological and theoretical terms is based on modern scientific works of Russian and foreign practitioners in the field of SMM.

The results of the study have practical significance for small and medium-sized businesses when making decisions on the use and development of promotion tools. Scientific research can provide a theoretical and methodological basis for further research on this topic, as well as used in practical terms.

\section{Список литературы}

1. Sisira N. Social Media and Its Role in Marketing // International Journal of Enterprise Computing and Business Systems. - 2011 [Electronic resource]. - Access mode: http://www.ijecbs.com/July2011/13.pdf

2. Saravanakumar M. Social Media Marketing / M. Saravanakumar, T. Suganthalakshmi // Life Science Journal. - 2012 [Electronic resource]. - Access mode: https://web.archive.org/web/20140607003438/http ://dems.unimib.it/corsi/817/esercit azioni/social_media_mktg.pdf 
3. Ortiz-Cordova A. Classifying Web Search Queries in Order to Identify High Revenue Generating Customers / A. Ortiz-Cordova, B.J. Jansen // Journal of the American Society for Information Sciences and Technology. - 2012 [Electronic resource]. - Access mode:

https://faculty.ist.psu.edu/jjansen/academic/jansen_high_revenue_customers_2012.pdf

4. Halilov D. Marketing v sotsialnyih setyah. -2016.

5. Beel J. Academic Search Engine Optimization (ASEO): Optimizing Scholarly Literature for Google Scholar and Co / J. Beel, B. Gipp, E. Wilde // Journal of Scholarly Publishing - 2010 [Electronic resource]. - Access mode: http://www.sciplore.org/publications/2010-ASEO--preprint.pdf 